\title{
PENGEMBANGAN MODUL PRAKTIKUM OSILOSKOP UNTUK MENINGKATKAN PEMAHAMAN KONSEP ARUS BOLAK-BALIK MAHASISWA POLITEKNIK NEGERI BANDUNG
}

\author{
I Gede Rasagama \\ Program Studi Teknik Aeroneutika, Politeknik Negeri Bandung \\ *Email: igesagama@polban.ac.id
}

DOI: http://dx.doi.org/10.29303/jpft.v5i1.1159

\begin{abstract}
The usefulness of the concept of alternating current is very functional for polytechnic students because it provides a basic theory of the production and use of electrical energy. At the Bandung Polytechnic Physics Laboratory, the oscilloscope practicum does not seem to have comprehensively verified the concept of alternating current. Understanding the concept of alternating current has become an urgent need and an indicator of the success of the learning process of Physics for graduates of DIII and DIV of several Bandung State Polytechnic study programs. The main objective of the research is to produce an oscilloscope practicum module that can support the learning of the concept of alternating current for Bandung State Polytechnic students through the optimization of the functions of existing equipment and the procurement of new equipment. Through the $R \& D$ approach (preliminary study, the design phase, development stage, and validation stage) have produced two digital oscilloscope practicum modules, which are assisted by Hantek-DSO-2090. The test results show: the two modules are able to verify the concept of alternating current; practicum with modules has a significant effect on increasing understanding of the concept of alternating current students; practicum module received positive responses from almost all students, and working on practicum modules is felt easy by students even though the material is considered difficult.
\end{abstract}

Keywords: Oscilloscope, Alternating Current, Concept Understanding.

PENDAHULUAN

\section{CRO (Cathode Ray Oscilloscope)}

termasuk salah satu peralatan sangat terandalkan untuk menganalisis bentuk gelombang yang dihasilkan oleh rangkaian elektronika termasuk rangkaian arus bolak balik (AC) (Hickman, 2001). Semua gejala fisis didalam CRO adalah bidang kajian fisika. Kompetensi mengoperasikan CRO juga sangat dibutuhkan dan telah menjadi satu tuntutan khusus mata pelajaran kompetensi kejuruan elektronika industri, program keahlian teknik elektronika industri di SMK Negeri 1 Kota Cimahi (Firdaus, 2014)

Dalam pembelajaran Fisika, katagori pemahaman konsep AC termasuk sulit. Mahasiswa harus memahami lebih dulu beberapa konsep pendukung. Pada setiap referensi Fisika Dasar, penyajian konsep ini selalu ada pada bagian akhir (Serway dan Cuille, 2018; Young dan Freedman, 2016). Keadaan ini juga didukung hasil riset
Nugroho et al. (2004) dan Pasal 5 Bab II Peraturan Presiden RI Nomor 8 Tahun 2012 tentang KKNI yaitu pemahaman merupakan capaian pembelajaran jenjang 5 (jenjang 6) kualifikasi lulusan DIII (DIV).

Potret terkini prihal praktikum osiloskop di Laboratorium Fisika Politeknik Negeri Bandung (LF-PNB) tampak belum ada rangkaian RC seri dan RLC seri. Praktikum baru memverifikasi konsep perioda, frekuensi, tegangan maksimum, dan arus efektif pada rangkaian RL seri. Praktikum belum memverifikasi konsep daya, faktor daya, dan gejala resonansi. Praktikum belum memanfaatkan CRO digital yang mampu menyimpan data praktikum (Suryadi, 2014). Riset ini juga urgen karena: (i) luarannya berupa metode pembelajaran berbasis eksperimen yang mampu mengkondisikan mahasiswa lebih aktif sehingga hasil belajar fisikanya meningkat (Nurqomariah et al, 2015); dan (ii) hasil kaji silabus matakuliah Fisika 
Tahun 2018 menunjukkan bahwa 75\% prodi DIII \& DIV Rekayasa yang ada di lingkungan PNB perlu pemahaman konsep AC.

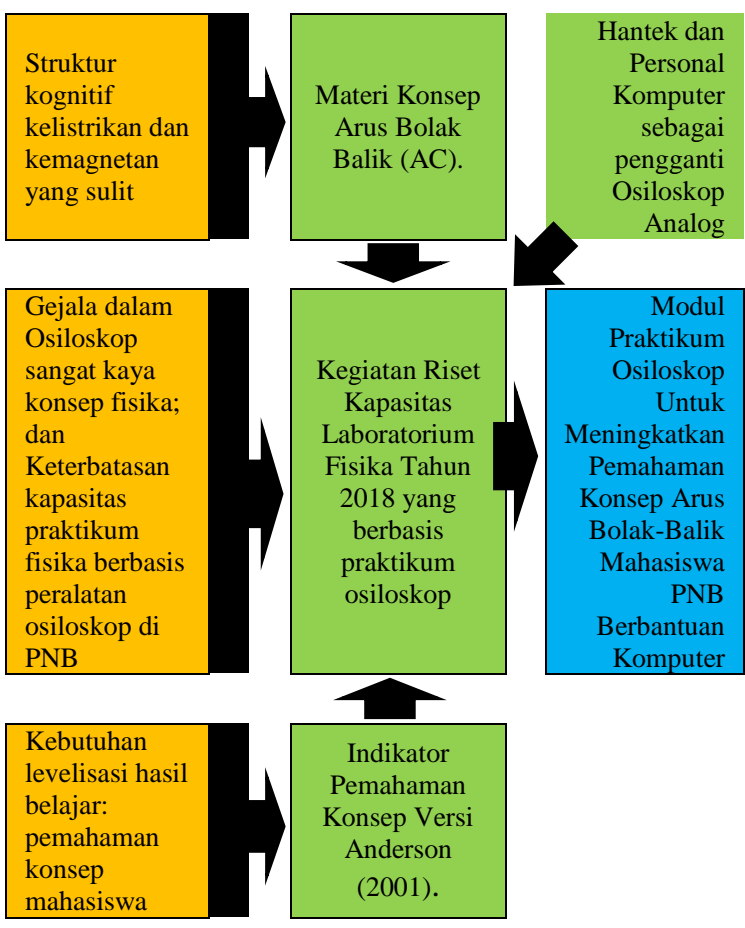

Gambar 1. Alur Berpikir Riset

Riset osiloskop oleh Shanti, M. R. S., et al. (2013); Dastoori, K. \& Makin, B. (2001); dan Rana, K.P.S., et al.(2009) tampak masih fokus pada masalah pengukuran besaran fisika, yang termasuk bidang riset non-pendidikan fisika. Didalam riset pendidikan fisika, khusus prihal pengembangan media pembelajaran belum ada pemanfaatan CRO. Ada produk diluar riset pendidikan fisika, yang dilakukan oleh Muhammad Firdaus (2014) yaitu pengembangan media pembelajaran buku elektronika interaktif untuk meningkatkan minat belajar siswa terhadap mata pelajaran kompetensi kejuruan elektronika industri dan kompetensi dasar mengoperasikan osiloskop, juga belum memanfaatkan CRO sebagai media pembelajaran guna pemahaman konsep fisika. Dari deskripsi diatas maka riset ini dilakukan dengan alur berpikir seperti tampak pada Gambar 1 .

Adapun tujuan riset guna mengetahui hal-hal berikut, yaitu: (i) modul praktikum osiloskop yang mampu meningkatkan pemahaman konsep AC mahasiswa; (ii) kesesuaian teori dalam modul praktikum riset dengan teori AC; (iii) apakah setelah penggunaan modul praktikum riset mampu memberi pemahaman konsep mahasiswa lebih tinggi dibanding sebelumnya?; (iv) tanggapan dan kesulitan mahasiswa selama menggunakan modul praktikum riset.

\section{METODE PENELITIAN}

Riset memakai subyek mahasiswa Kelas IA DIII Prodi Teknik Mesin. Rancangan riset memakai pendekatan $R \& D$, yang mengacu kepada Gall et al. (1979) meliputi:

1. Studi pendahuluan:

a. Studi literatur prihal: peralatan osiloskop, konsep AC, dan pemahaman konsep versi Anderson (2001). Berbasis hasil literasi referensi terkait dapat didraft seting peralatan dan modul praktikum Osiloskop, serta instrumen asesmen pemahaman konsep AC, hasil belajar mahasiswa.

b. Inventarisasi unit-unit alat terkait, fungsional, esensial, dan yang ada di LF-PNB. Dicek keberfungsiannya sehingga dapat diketahui ada atau tidaknya kebutuhan perbaikan atau pengadaan unit peralatan baru. Dari hasil perhitungan teoritis, maka finalisasi nama dan jumlah unit alat, serta seting peralatan praktikum osiloskop, yang selaras dengan hasil literasi referensi dapat dilaksanakan.

2. Tahap perancangan:

a. Penyusunan uraian materi, analisis konsep, dan analisis sub-sub indikator pemahaman konsep AC.

b. Penyusunan modul praktikum osiloskop, disesuaikan dengan hasil studi pendahuluan.

c. Penyusunan instrumen pengukuran mutu produk riset, yaitu: (i) 40 soal PG untuk mengukur peningkatan 
pemahaman konsep AC mahasiswa, sebelum dan setelah penggunaan modul praktikum riset; (ii) 10 soal angket untuk mengukur tanggapan mahasiswa terhadap modul praktikum riset, dan (iii) 5 soal angket untuk mengetahui kesulitan mahasiswa selama praktikum menggunakan modul riset.

3. Tahap pengembangan:

a. Ujicoba I modul praktikum oleh peneliti di LF-PNB melalui percobaan untuk pengukuran besaran-besaran fisika yang diinginkan dan melalui perhitungan yang memastikan kesesuaian antara hasil eksperimen dengan teori AC. Temuan tidak relevan dengan teori dijadikan dasar penyempurnaan modul praktikum riset. Ujicoba ini juga memperhatikan efisiensi dan efektivitas waktu penerapan modul di lapangan.

4. Tahap validasi:

a. Tes I mengukur tingkat pemahaman konsep AC mahasiswa sebelum memakai modul praktikum riset.

b. Ujicoba II modul praktikum oleh mahasiswa dengan mengikuti SOP dalam modul praktikum riset. Dilakukan asesmen komprehensif terhadap isian modul praktikum mahasiswa untuk tujuan validasi dan revisi modul praktikum riset.

c. Tes II mengukur tingkat pemahaman konsep AC mahasiswa setelah memakai modul praktikum riset.

d. Pengisian angket tanggapan dan angket kesulitan, setelah mahasiswa memakai modul praktikum riset. Analisis isi kedua angket untuk tujuan validasi dan revisi modul praktikum riset.

e. Validasi melalui pengukuran signifikansi dampak penggunaan modul praktikum bagi mahasiswa berdasarkan data nilai tes sebelum dan setelah penggunaan modul praktikum riset. Melalui analisa data hasil tes I, tes II, dan uji statistik maka taraf signifikansinya dapat diketahui. Ini memberi informasi prihal mutu produk riset yang telah dikembangkan.

\section{HASIL DAN PEMBAHASAN}

Hasil inventarisasi alat ditunjukkan oleh Tabel 1. Disamping itu juga ditemukan alat yang terkait meliputi: 1 hambatan geser dengan hambatan variabel antara 2 s.d $240 \Omega$; dan 1 generator sinyal dengan frekuensi variabel antara 1 s.d. $109,4 \mathrm{kHz}$ dan tegangan maksimum variabel, antara 0 s.d 6,6V (pengukuran multimeter analog).

Melalui hasil inventarisasi diatas maka dapat didesain beberapa rangkaian $\mathrm{RC}$ seri dan RLC seri yang belum ada di modul lama dan yang mungkin diseting.

Untuk hasil kajian terhadap modul praktikum osiloskop yang ada, yang akan dikembangkan, dan perhitungan teoritis, ditunjukkan oleh Tabel 2. Dengan alasan bahwa variabel hasil pengukuran harus measurable dan obsevable maka ditetapkan:

1. Untuk rangkaian $\mathrm{RC}$ seri $V_{\max }$ berubah $f$ tetap, ditetapkan memakai komponen kapasitor dengan kapasitansi $(C) 0,1 \mu \mathrm{F}$ dan komponen resistor dengan resistansi $(R) 80 \Omega$. Frekuensi generator sinyal $(f)$ dikondisikan tetap $400 \mathrm{~Hz}$ dan interval variabel tegangan maksimum $\left(V_{\max }\right)$ dari $1 \mathrm{~V} ; 2 \mathrm{~V} ; 2,5 \mathrm{~V} ; 3 \mathrm{~V} ; 4 \mathrm{~V} ; 5 \mathrm{~V}$; $5,5 \mathrm{~V} ;$ s.d $6 \mathrm{~V}$.

2. Untuk rangkaian $\mathrm{RC}$ seri $f$ berubah $V_{\max }$ tetap, ditetapkan memakai komponen kapasitor $C=0,1 \mu \mathrm{F}$ dan komponen resistor $R=80 \Omega$. $V_{\max }$ generator sinyal diatur pada kondisi tetap $6 \mathrm{~V}$ dan interval variabel $f$ dari $400 \mathrm{~Hz} ; 800 \mathrm{~Hz}$; $1,2 \mathrm{kHz} ; \quad 1,6 \mathrm{kHz} ; \quad 2 \mathrm{kHz} ; \quad 2,4 \mathrm{kHz}$; $2,8 \mathrm{kHz}$; s.d $3,2 \mathrm{kHz}$.

3. Untuk rangkaian RLC seri $f$ berubah, $V_{\max }$ tetap, dan keadaan resonansi, 
ditetapkan memakai komponen kapasitor $\mathrm{C}=0,1 \mu \mathrm{F}$; induktor dengan induktansi $(L) 36 \mathrm{mH}$; dan komponen resistor dengan $R$ variabel pada nilai $10 \Omega, 20 \Omega, 40 \Omega$, dan $80 \Omega$. $V_{\max }$ generator sinyal diatur pada kondisi tetap $6 \mathrm{~V}$ dan interval variabel $f$ dari $500 \mathrm{~Hz} ; \quad 2 \mathrm{kHz} ; \quad 2,3 \mathrm{kHz} ; \quad 2,5 \mathrm{kHz}$; $2,652 \mathrm{kHz} ; 3 \mathrm{kHz} ; 3,5 \mathrm{kHz} ; 4 \mathrm{kHz}$; s.d $12 \mathrm{kHz}$.

Tabel 1. Inventarisasi Alat Praktikum

\begin{tabular}{|c|c|c|}
\hline Alat & Spesifikasi & Jumlah \\
\hline Resistor & $\begin{array}{l}\mathrm{R}_{1}=10 \Omega, \mathrm{R}_{2}=20 \\
\Omega, \mathrm{R}_{3}=40 \Omega \text {, dan } \\
\mathrm{R}_{4}=80 \Omega, \mathrm{a} \\
\mathrm{P}_{\max }=10 \mathrm{~W} \text { dalam } \\
1 \text { set peralatan. }\end{array}$ & 2 \\
\hline \multirow[t]{3}{*}{ Kapasitor } & $\begin{array}{l}\mathrm{C}_{1}=0,1 \mu \mathrm{F} \mathrm{V} \mathrm{V}_{\max } \\
=400 \mathrm{~V}\end{array}$ & 3 \\
\hline & $\begin{array}{l}\mathrm{C}_{2}=250 \mathrm{pF} \mathrm{V} \text { max } \\
=400 \mathrm{~V}\end{array}$ & 1 \\
\hline & $\begin{array}{l}\mathrm{C}_{3}=1000 \mathrm{pF} \\
\mathrm{V}_{\max }=400 \mathrm{~V} \text { dan } \\
63 \mathrm{~V}\end{array}$ & 2 \\
\hline \multirow[t]{2}{*}{ Induktor } & $\begin{array}{l}\mathrm{L}_{1}=9 \mathrm{mH} \\
\text { dengan } \mathrm{N}=500, \\
\mathrm{R}=2,5 \Omega \text {, dan } \\
\mathrm{I}_{\max }=2,5 \mathrm{~A}\end{array}$ & 1 \\
\hline & $\begin{array}{l}\mathrm{L}_{2}=36 \mathrm{mH} \\
\text { dengan } \mathrm{N}=1000, \\
\mathrm{R}=9,5 \Omega, \text { dan } \\
\mathrm{I}_{\max }=1,25 \mathrm{~A}\end{array}$ & 1 \\
\hline
\end{tabular}

Tabel 2. Hasil Kaji Kondisi Modul dan Perhitungan Teoritisnya.

\begin{tabular}{cl}
\hline Tipe Data & \multicolumn{1}{c}{ Temuan } \\
\hline Modul lama & Belum memuat rangkaian \\
& RC dan RLC seri serta \\
& hanya membahas unit-unit \\
& konsep AC terbatas \\
& berbasis CRO analog \\
\hline Modul baru & Melengkapi unit-unit \\
& konsep AC “yang belum \\
& ada” di modul lama \\
& berbasis CRO digital \\
\hline
\end{tabular}

\begin{tabular}{|c|c|}
\hline Tipe Data & Temuan \\
\hline \multirow{11}{*}{$\begin{array}{l}\text { Perhitungan } \\
\text { teoritis }\end{array}$} & 96 perhitungan $(Z, I)$ \\
\hline & berbeda di RC seri $V_{\max }$ \\
\hline & berubah f tetap $400 \mathrm{~Hz}$ \\
\hline & 96 perhitungan \\
\hline & $(Z, I, P, \operatorname{Cos} \varphi)$ berbeda di \\
\hline & $\mathrm{RC}$ seri $\mathrm{f}$ berubah $\mathrm{V}_{\max }$ \\
\hline & tetap $6,0 \mathrm{~V}$; dan \\
\hline & 160 perhitungan \\
\hline & $\left(X_{L}, X_{C}, Z, I\right)$ berbeda di \\
\hline & RLC seri pada $V_{\max }$ tetap \\
\hline & $(6,0 \mathrm{~V})$ Resonansi \\
\hline
\end{tabular}

Sesuai kebutuhan karakteristik data maka pengembangan modul praktikum memerlukan pengukur $V_{\max }$, arus efektif ( $I$ ), dan $f$ generator sinyal AC. Untuk pengukur $V_{\text {max }}$ dan $f$ generator sinyal AC, digunakan Hantek DSO2029 USB Oscoloscope 4OMHz berbantuan PC (Suryadi, 2014). Melalui install aplikasinya pada $\mathrm{PC}$, peralatan ini dapat mengganti fungsi $C R O$ analog, yang mampu menyimpan data praktikum sebagai dokumen. Untuk pengukur arus efektif digunakan multimeter digital Sanwa yang ada di LF-PNB.

Pada tahap perancangan dihasilkan draft modul praktikum osiloskop rangkaian AC RC seri sebagai draf modul I dan RLC seri sebagai draf modul II. Sub-sub isi dari draft ke-2 modul tersebut meliputi: judul, tujuan, dasar teori, alat dan bahan, kondisi ruangan, langkah percobaan, pertanyaan, simpulan, sumber kesalahan, dan daftar pustaka.

Desain isi modul I untuk mengakomodasi: (i) pencapaian kompetensi 4 sub indikator pemahaman konsep (SIPK) pertama versi Anderson (2001); (ii) pemahaman konsep impedansi $(Z)$, daya efektif $(P)$, faktor daya $(\operatorname{Cos} \varphi)$ dan keterkaitan impedansi, daya efektif, dan faktor daya dengan perubahan $f$; dan (iii) pengukuran tak langsung terhadap $R$ dan $C$ dalam rangkaian AC. Konsep $L$ tidak 
dimunculkan disini karena modulnya telah ada di LF-PNB.

Desain isi modul II untuk mengakomodasi: (i) pencapaian kompetensi dalam 3 SIPK terakhir versi Anderson (2001).; (ii) pemahaman konsep $I$ dan keterkaitannya dengan perubahan $f$ dan $R$ dalam rangkaian $\mathrm{AC}$; dan (iii) pemahaman keadaan resonansi rangkaian $\mathrm{AC}$ dan dampaknya terhadap besaran-besaran seperti $Z, I, V_{\text {eff, }}$, beda sudut fase antara tegangan dan arus listrik $(\varphi), P$, dan $\operatorname{Cos} \varphi$ rangkaian $\mathrm{AC}$.

Ke-2 modul juga didesain berdasarkan hasil kaji sebelumnya, yang dilakukan secara bertahap, yaitu hasil kaji uraian materi $\mathrm{AC}$, analisis konsep $\mathrm{AC}$, dan analisis SIPK AC. Pada kaji uraian materi AC dipetakan konsep-konsep esensial dan fungsional dalam materi AC sebagai konsep utama yang disajikan ke mahasiswa melalui modul praktikum. Dengan ini dapat dipastikan semua konsep dalam pokok bahasan AC telah teridentifikasi dengan baik.

Pada analisis konsep AC dikaji karakteristik setiap konsep (tunggal) dalam pokok bahasan AC secara mendalam (eksplisit dan implisit) sehingga unit-unit terkait dengan konsep telah teridentifikasi dengan baik seperti label, jenis, definisi, atribut (kritis \& variabel), hirarki (super, ko, $\&$ sub ordinat), contoh dan non contoh.

Pada analisis SIPK versi Anderson (2001), dikonversikan arti SIPK umum versi Anderson (2001) kedalam SIPK arti khusus berbasis materi AC. Arti khusus ini dijadikan pedoman untuk menyusun unit aktivitas praktikum dan soal evaluasi (pertanyaan). Aktivitas praktikum berupa mengcreate data real besaran fisika melalui percobaan, mengobservasi gejala fisika yang terjadi dalam percobaan, dan menganalisis data hasil percobaan. Unit soal evaluasi diarahkan pada kegiatan mahasiswa untuk menstimulasi pra-kognitif, memperbaiki miskonsepsi, menambah pemahaman konsep baru, memperkuat pemahaman konsep lama. Kedua unit ini yang ada dalam analisis SIPK dijadikan sebagai landasan utama untuk merumuskan tugas pendahuluan, langkah percobaan dan pertanyaan didalam kedua desain modul praktikum osiloskop yang dikembangkan.

Soal PG dirancang berbasiskan hasil kaji isi tiap sel dalam "kolom soal evaluasi (pertanyaan)" yaitu 7 SIPK yang ingin dicapai dalam KBM melalui implementasi modul praktikum. Rincian soalnya, antara lain:

1. SIPK1 yaitu mengubah representasi tegangan maksimum dan arus efektif menjadi impedansi didalam rangkaian AC RC seri. Jumlahnya 5 soal;

2. SIPK2 yaitu mengidentifikasi deskripsi konsep $Z$ dalam konsep umum diagram fasor $\left(Z^{2}=R^{2}+X_{C}^{2}\right)$ dan hukum Ohm $\left(Z=\frac{V_{\max }}{\sqrt{2} I}\right)$, lalu mengkonstruksi konsep khusus $R$ dan $C$ pada rangkaian AC RC seri. Jumlahnya 7 soal;

3. SIPK3 yaitu mendeteksi pola hubungan matematis antara $P$ dengan $f$ generator sinyal, relevan dengan konsep umum dan konsep khusus, pada kondisi $R, C$, $V_{\text {eff }}$ generator sinyal tetap, dan kondisi $f$ generator sinyal berubah. Konsep umum: diagram fasor hubungan $Z$ $\left(\mathrm{Z}^{2}=\mathrm{R}^{2}+\mathrm{X}_{\mathrm{c}}^{2}\right)$ dan reaktansi kapasitor $\left(X_{c}=(2 \pi f C)^{-1}\right)$ dan Hukum Ohm $\left(\mathrm{Z}=\frac{V_{\max }}{I \sqrt{2}}\right)$. Konsep khusus: $P\left(P=I^{2} R\right)$. Jumlahnya 5 soal;

4. SIPK4 yaitu mengkonstruksi pernyataan tunggal prihal $\operatorname{Cos} \varphi$ terkait dengan perubahan $f$ generator sinyal dalam rangkaian RC seri, sebagai representasi informasi menurunnya $Z$ karena meningkatnya $f$ pada keadaan $R, C$, dan $V_{\text {eff }}$ generator sinyal berharga tetap. Jumlahnya 5 soal;

5. SIPK5 yaitu menemukan pola khusus prihal $I$ tertinggi keadaan resonansi pada beberapa nilai $f$ generator sinyal dalam 
rangkaian AC RLC seri. Jumlahnya 7 soal;

6. SIPK6 yaitu mendeteksi perbedaan arus efektif pada 2 keadaan resonansi rangkaian AC RLC seri dengan nilai $R$ berbeda. Jumlahnya 5 soal;

7. SIPK7 yaitu mengkonstruksi model sebab akibat antar unit mayor dalam sistem, lalu memakai untuk memprediksi dampak perubahan salah satu unit mayor terhadap unit mayor lain, terkait dengan keadaan resonansi rangkaian AC RLC seri. Jumlahnya 6 soal.

Setiap kisi dan soal disusun berdasarkan hasil analisis unit-unit proses berpikir mahasiswa, yang mungkin dimunculkan oleh setiap SIPK melalui KBM praktikum. Terkait dengan kuantitas dan kualitas konsep implisit pada setiap SIPK tampak bahwa setiap SIPK memuat 5 atau 6 atau $7 \mathrm{kisi} / \mathrm{soal}$.

Pengembangan bahan ajar dan perangkat pendukungnya termasuk soal yang dikembangkan perlu mempertimbangkan beberapa aspek sehingga lebih kontekstual dan dapat meningkatkan penguasaan konsep maupun keterampilan berpikir peserta didik (Sutrio et al. 2018; Oktaviani et al. 2017).

Angket tanggapan disusun untuk mengukur tanggapan mahasiswa setelah memakai modul praktikum riset. Disisi lain juga untuk mengetahui persepsi tingkat pemahaman mahasiswa, prihal konsep AC yang dipelajari mahasiswa selama KBM melalui modul praktikum.

Hal-hal sentral menjadi dasar penilaian dalam angket tanggapan mahasiswa adalah: (i) kesesuaian antara sistematika tampilan modul dengan langkahlangkah percobaan; (ii) kejelasan tujuan praktikum; (iii) kejelasan dasar teori dan kesesuaiannya dengan tujuan; (iv) kemudahan identifikasi alat-alat saat praktikum melalui alat-alat yang tertulis dalam modul; (v) dampak tugas pendahuluan terhadap pemahaman konsep AC; (vi) kemampuan langkah-langkah percobaan dalam memandu praktikum; (vii) kualitas tabel isian data dalam memudahkan pencatatan dan pengolahan data; (viii) kualitas pertanyaan dalam mengeksplorasi pemahaman mahasiswa setelah praktikum; (ix) kebosanan mahasiswa dalam mengikuti perkuliahan AC karena adanya praktikum osiloskop; dan (x) dampak praktikum dalam memberikan gambaran persoalan-persoalan Fisika, khususnya AC.

Angket kesulitan disusun untuk mengetahui kesulitan mahasiswa selama menggunakan modul praktikum. Angket ini berisi pertanyaan dengan jawaban uraian disesuaikan dengan kondisi yang dialami mahasiswa selama menggunakan modul praktikum. Persepsi kesulitan dalam angket mahasiswa ini adalah dalam hal:: (i) materi AC secara umum, (ii) penjelasan materi pada modul praktikum, (iii) petunjuk praktikum pada modul praktikum; (iv) pengambilan data ketika praktikum; (v) kesulitankesulitan lainnya.

Hasil ujicoba modul praktikum oleh peneliti di LF-PNB memberikan sejumlah temuan berarti bagi perbaikan modul praktikum riset. Rincian temuan dan tindaklanjutnya adalah sbb:

1. Nilai $V_{\max }$ tertinggi yang dapat diukur oleh Hantek DSO2090 USB PC Osciloscope pada layar PC $\pm 1,0 \mathrm{~V}$. Ini sesuai dengan hint yang tertulis pada bagian luar generator sinyal, yaitu $\pm 1,0 \mathrm{~V}$ (x20 mVpp x100). Temuan ini merubah hasil studi pendahuluan dimana pengukuran $V_{\max }$ tertinggi yang dihasilkan oleh generator sinyal adalah $\pm 6,0 \mathrm{~V}$ (berbasis pengukuran multimeter analog secara langsung dimana kondisi komponen listrik lain dalam rangkaian off). Dengan demikian ditetapkan praktikum memakai interval $\mathrm{V}_{\max }$ dari $139 \mathrm{mV}$ s/d $967 \mathrm{mV}$. 
2. Nilai $\mathrm{V}_{\max }$ tidak dapat dikondisikan tetap ketika ada perubahan $f$ generator sinyal. Pada kondisi 8x pengukuran dengan frekuensi berbeda, aplikasi Hantek DSO2090 USB PC Oscilloscope melalui layar PC tampak fluktuasi $V_{\max } \pm 15 \mathrm{mV}$.

3. Hantek DSO2090 USB PC Oscilloscope melalui layar PC dapat menunjukkan gejala gelombang sinusoidal dan terobservasi dengan baik, termasuk nilai $V_{\text {max }}, f$, dan besaran terkait lainnya.

4. Hantek DSO2090 USB PC Oscilloscope dapat mengakomodasi interval pengukuran $f$ seperti ditetapkan dalam studi pendahuluan $(500 \mathrm{~Hz}$ s/d $12000 \mathrm{~Hz})$. Nilai $f$ ini sesuai dengan hint yang tertulis pada permukaan kotak generator sinyal.

5. Nilai $I$ hasil pengukuran (eksperimen) dengan multimeter digital Sanwa pada setiap rangkaian, baik RC seri dan RLC seri cenderung bernilai 10x dibanding hasil perhitungan teoritis. Ketika multimeter digital Sanwa diganti dengan multimeter digital Pudak malahan I rangkaian terukur sangat kecil dan tidak terbaca. Namun dengan multimeter digital Sanwa telah menunjukkan gejala perubahan nilai $I$ sesuai pengkondisian yang diperlukan, masih selaras dengan teori/konsep AC yang berlaku.

Maksud perhitungan teoritis dalam pernyataan "nilai $I$ yang diukur oleh multimeter digital cenderung sama dengan $\pm 10 x$ I hasil perhitungan teoritis" diatas adalah perhitungan berbasis konsep Hukum Ohm. Penyebab keadaan ini terjadi karena: (i) tidak validnya nilai $R$ resistor, $C$ kapasitor, dan $L$ induktor yang tertera dalam setiap komponen listrik terhadap nilai sesungguhnya karena tidak pernah dikalibrasi; dan (ii) tidak validnya hasil pengukuran yang ditunjukkan oleh multimeter digital Sanwa dengan hasil pengukuran sesungguhnya karena tidak ada bukti bahwa multimeter digital Sanwa terkait telah dikalibrasi.

Pada rangkaian $\mathrm{RC}$ seri, perubahan $V_{\max }$ pada $f$ tetap tampak $V_{\max }$ makin besar menyebabkan $I$ makin besar, baik ditunjukkan oleh multimeter digital maupun hasil perhitungan teoritis. Untuk kondisi $V_{\max }$ tetap, $f$ makin besar menyebabkan $I$ juga makin besar, baik ditunjukkan oleh multimeter digital dan perhitungan teoritis.

Pada rangkaian RLC seri, akibat pengkondisian $f$ makin besar pada kondisi $V_{\max }$ tetap, menyebabkan $I$ makin besar, kemudian mencapai nilai maksimum, dan pada akhirnya makin kecil. Ini ditunjukkan oleh hasil pengukuran multimeter digital dan perhitungan teoritis. Ketika I mencapai nilai maksimum, $f$ sumber (generator sinyal) hampir sama $f$ rangkaian $\left(f_{0}=\frac{1}{2 \pi \sqrt{L C}}\right.$ ). Kondisi ini disebut resonansi.

Validasi ke-2 modul praktikum dilakukan di LF-PNB oleh 31 mahasiswa atau 8 kelompok praktikum, selaku subjek riset. Kegiatan ini diawali dengan pre-test, lalu ujicoba modul praktikum, post-test dan diakhiri pengisian angket tanggapan serta angket kesulitan.

Hasil observasi selama ujicoba modul praktikum tampak bahwa mahasiswa dalam mengerjakan tugas pendahuluan dan pertanyaan sangat tergantung pada mahasiswa yang dianggap terpandai di kelompok atau di kelas terkait. Diskusi antar mahasiswa dalam kelompok dan literasi referensi terkait tidak terlalu tampak. Mayoritas mahasiswa hanya mengandalkan modul praktikum yang dibagikan peneliti sebagai sumber bacaan. Kemandirian mahasiswa dalam mengerjakan laporan masih sangat kurang sehingga mayoritas isi modul praktikum yang dikumpulkan tampak sangat homogen. Capaian rerata nilai laporan mahasiswa 70,5 (tujuh puluh koma lima). 
Data hasil pre-test, post-test, dan perolehan normalisasi gain ( $N$-Gain) mahasiswa ditunjukkan oleh Gambar 2. Hasil uji statistik menunjukkan: (i) data pretest dan post-test mempunyai sebaran normal; (ii) pasangan data post-test vs pretest bersifat non homogen; dan (iii) taraf signifikansi hasil hitung SPSS melalui uji non parametrik (Wilcoxon Signed Ranks Test) dibawah 5\%. Ini berarti ada pengaruh signifikan penggunaan modul praktikum terhadap pemahaman konsep AC mahasiswa walaupun katagori $N$-Gain mahasiswa masih rendah.

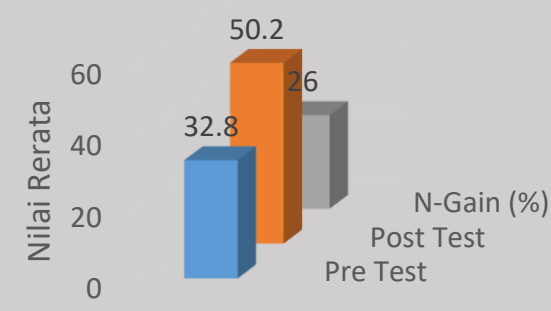

Gambar 2. Pre-Test, Post-Test, dan NGain Pemahaman Konsep Mahasiswa

Peningkatan $N$-Gain katagori rendah ini dapat ditingkatkan melalui perbaikan kualitas kemandirian mahasiswa dalam mengerjakan modul, kualitas diskusi kelompok antar mahasiswa, dan kemampuan literasi sains-fisika. Pengerjaan modul harus melalui pengawasan melekat dan terkendali sehingga selama proses pengerjaan modul tersebut tidak ada fenomena menjiplak atau mencontek pekerjaan teman.

Analisis hasil angket tanggapan seluruh mahasiswa, setelah memakai modul praktikum riset tampak sebanyak 23\% Sangat Setuju, 57\% Setuju, 17\% Biasa Saja, 3\% Tidak Setuju, dan 0\% Sangat Tidak Setuju. Ini berarti $80 \%$ mahasiwa memberi tanggapan positif terhadap modul praktikum yang dikembangkan. Isi modul yang dikembangkan telah memenuhi standar sebagai modul praktikum yang mampu membantu mahasiswa dalam meningkatkan pemahaman konsep AC dan konsep dasar lainnya. Aktivitas pemahaman konsep AC mahasiswa telah dicreate dengan baik dalam modul yang dikembangkan.

Kesulitan mahasiswa dalam menggunakan modul yang dikembangkan, dapat dijelaskan dari 2 sisi, antara lain: (i) materi pokok bahasan AC tampak 90\% mahasiswa menyatakan sulit (katagori: cukup sulit, sulit, dan sangat sulit); dan (ii) persepsi kualitas isi modul tampak 97\% mahasiswa merasa mudah (katagori: sangat mudah, mudah, dan cukup mudah) memakai modul selama praktikum. Dengan demikian hasil angket ini sangat mendukung hasil angket tanggapan mahasiswa yaitu modul yang dikembangkan telah memenuhi standar sebagai modul praktikum untuk membantu mahasiswa dalam meningkatkan pemahaman konsep AC dan konsep-konsep dasar terkait telah dicreate dengan baik dalam modul yang dikembangkan.

Berdasarkan ke-2 hasil angket diatas terungkap beberapa catatan terkait dengan penggunaan produk riset di lapangan ke depan, antara lain: (i) hantek digital telah mempermudah dalam hal pengambilan data dibanding osiloskop analog dan bisa disimpan sebagai file data; (ii) ada kesulitan pengkondisian nilai $V_{\max }$ dan $f$ seperti yang diinginkan karena sensitivitas hantek digital yang tinggi; (iii) pembacaan oleh hantek kadang-kadang error karena waktu pengukuran yang lama sehingga perlu kondisi on-off sistem peralatan selama tahapan pengukuran berlangsung; (iv) pengolahan data yang banyak sesuai tuntutan jumlah konsep yang harus dipahami, sangat diperlukan pengolahan data dengan aplikasi microsoft excel; dan (v) pertanyaan-pertanyaan dalam modul masih dianggap sulit sesuai persepsi oleh mahasiswa yang belum memahami konsep AC, khusus konsep berbasis perhitungan. Catatan ini tidak merubah isi modul hasil 
tahap pengembangan, namun lebih memberi penekanan prihal kualitas proses pengerjaan modul praktikum oleh setiap mahasiswa yang masih kurang. Eleminasi proses harus direalisasikan yaitu mayoritas mahasiswa mencontek atau menjiplak pekerjaan teman yang dianggap lebih pintar tanpa ada diskusi dan elaborasi secara individu atau mandiri lebih dulu.

\section{PENUTUP}

Berdasarkan analisa data, hasil temuan, dan pembahasan dapat dikemukakan beberapa kesimpulan riset, antara lain:

1. Modul praktikum osiloskop untuk meningkatkan pemahaman konsep AC mahasiswa PNB terdiri atas 2 modul antara lain: untuk rangkaian $\mathrm{AC}$ susunan $\mathrm{RC}$ seri dan untuk rangkaian $\mathrm{AC}$ susunan RLC seri. Modul I mengandung kekhasan antara lain: (i) pengembangan kompetensi 4 SIPK pertama versi Anderson (2001); (ii) pengukuran tidak langsung $Z$ melalui penerapan Hukum Ohm dalam rangkaian AC RC seri; (iii) penekanan pada pemahaman konsep $Z$, $P$, dan $\operatorname{Cos} \varphi$, serta keterkaitannya dengan perubahan $f$ sumber $\mathrm{AC}$ rangkaian RC seri; dan (iv) pengukuran tidak langsung $R$ resistor dan $C$ kapasitor. Modul II mengandung kekhasan antara lain: (i) pengembangan kompetensi 3 SIPK terakhir versi Anderson (2001); (ii) penekanan pada pemahaman konsep $I$ dan keterkaitannya dengan perubahan $f$ sumber dan $R$ resistor rangkaian AC RLC seri; dan (iii) penekanan pada pemahaman konsep keadaan resonansi dan dampaknya terhadap besaranbesaran fisika terkait pada rangkaian AC RLC seri. Kedua modul memanfaatkan peralatan digital Hantek DSO2090 USB PC Osiloskop $40 \mathrm{MHz}$ yang dikombinasi dengan PC sebagai pengganti fungsi osiloskop analog.
2. Modul praktikum osiloskop baik untuk rangkaian $\mathrm{AC} \mathrm{RC}$ seri dan rangkaian $\mathrm{AC}$ RLC seri mampu memverifikasi keberlakuan Hukum Ohm dan keterkaitan atau ketergantungan setiap besaran fisika dalam konsep AC, seperti $I, Z, P$, dan $\operatorname{Cos} \varphi$ terhadap perubahan $f$ sumber AC. Khusus untuk rangkaian AC RLC seri juga mampu memverifikasi fenomena-fenomena yang berlaku dalam keadaan resonansi. Walaupun nilai pengukuran langsung $I$ melalui multimeter digital belum terverifikasi dari nilai perhitungan $I$ secara teoritis namun gejala fisika yang ditunjukkan oleh seting peralatan dalam modul ini sudah sangat layak digunakan dalam KBM praktikum.

3. Praktikum memakai modul praktikum osiloskop yang dikembangkan telah memberikan peningkatan pemahaman konsep AC secara signifikan pada mahasiswa pada taraf signifikansi $5 \%$.

4. Praktikum dengan modul praktikum osiloskop yang dikembangkan mendapat tanggapan positif dari hampir seluruh mahasiswa kelas IA Prodi Teknik Mesin DIII PNB.

5. Kesulitan penggunaan modul praktikum osiloskop yang dikembangkan hampir tidak ada walaupun persepsi mahasiswa terhadap pokok bahasan AC adalah sulit.

Berdasarkan evaluasi kegiatan selama melaksanakan riset, berikut ini dikemukakan beberapa saran, antara lain:

1. Pelaksanaan praktikum dengan modul praktikum osiloskop yang dikembangkan harus dikondisikan sedemikian rupa sehingga selama proses pengerjaan modul tidak memberikan kesempatan kepada mahasiswa untuk mencontek atau menyalin pekerjaan teman, tanpa melakukan kegiatan elaborasi terlebih dahulu secara individu (mandiri). 
2. Pelaksanaan praktikum dengan 2 modul praktikum osiloskop produk riset merupakan 2 kegiatan terpisah, dimana setiap modul membutuhkan waktu 3-4 jam perkuliahan (a'50 menit) untuk pengambilan data dan pengerjaan modul.

\section{UCAPAN TERIMAKASIH}

Terimakasih kepada pihak UPPM PNB yang telah memfasilitasi pendanaan riset kapasitas lab ini, melalui kegiatan hibah kompetitif di lingkungan PNB.

\section{REFERENSI}

Anderson, L.W. 2001. A Taxonomy for Learning, Teaching, and Assessing: A Revision of Bloom's Taxonomy of Educational Objectives. New York: Addison Wesley Longman Inc.

Borg, W. R., Gall, M. D., \& Gall, J. P. 1979. Educational Research an Introduction. Fifth Edition. New York: Longman.

Dastoori, K. dan Makin, B. 2001. Adhesion Measurements for Electrostatic Powder Coatings Using Drop Test Rig and Virtual Oscilloscope. Journal of Electrostatics, 51-52, 509-514.

Firdaus, M. 2014. Visualisasi Prinsip Kerja Osiloskop Melalui Buku Elektronik Interaktif. Skripsi S1, UPI Bandung.

Hickman, I. 2001. Oscilloscope, How to Use Them, How They Work, Fifth Edition. Amsterdam: Newes.

Nugroho, Murni. T. 2004. Pembuatan Tes Diagnostik Fisika Pokok Bahasan Listrik Statis. Skripsi. Tidak diterbitkan.

Nurqomariah, N., Gunawan, \& Sutrio. 2015. Pengaruh Model Problem Based Learning dengan Metode Eksperimen Terhadap Hasil Belajar IPA Fisika Siswa Kelas VII SMP Negeri 19 Mataram Tahun Pelajaran 2014/2015. Jurnal Pendidikan Fisika dan Teknologi, 1(3), 173-179.
Oktaviani, W., Gunawan, \& Sutrio. 2017. Pengembangan Bahan Ajar Fisika Kontekstual Untuk Meningkatkan Penguasaan Konsep Siswa. Jurnal Pendidikan Fisika dan Teknologi, 3(1), 1-7.

Rana, K. P. S., Singh, R., \& Sayann, K. S. (2010). Correlation based novel technique for real time oscilloscope triggering for complex waveforms. Measurement, 43(3), 299-311.

Serway, A.R. \& Cuille, C. 2018. College Physics, Eleventh Edition, Cengage Learning 20 Channel Center Street Boston, MA 02210 USA.

Shanti, M. R. S., Oktaviara, A., Sutresno, A., \& Wibowo, N. A. (2014). Pembuatan media pembelajaran pengukuran viskositas dengan menggunakan viskometer dua kumparan dan freewave3. Jurnal Pendidikan Fisika Indonesia, 10(1). 28-35.

Suryadi, 2014. Probe Untuk Oscilloscope Portable Berbasis Laptop. Tugas Akhir DIV, Politeknik Negeri Batam.

Sutrio, S., Gunawan, G., Harjono, A., \& Sahidu, H. (2018). Pengembangan Bahan Ajar Fisika Eksperimen Berbasis Proyek Untuk Meningkatkan Keterampilan Berpikir Kritis Calon Guru Fisika. Jurnal Pendidikan Fisika dan Teknologi, 4(1), 131-140.

Young, H.D. \& Freedman, R.A. 2016. University Physics with Modern Physics. 14th Edition. Pearson Education, Inc. 